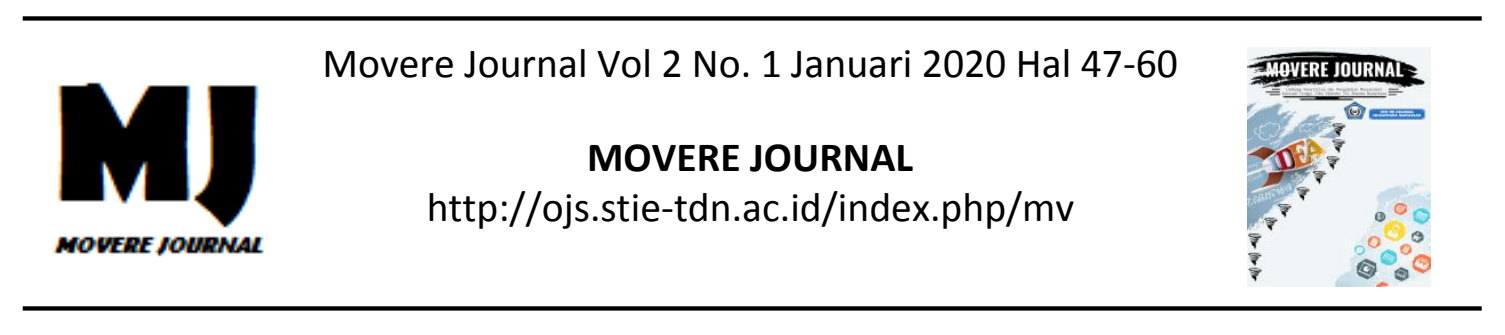

\title{
EVALUASI KINERJA DALAM MEWUJUDKAN KOMPETENSI PEDAGOGIK GURU HONORER UNTUK PENINGKATAN MUTU PEMBELAJARAN SISWA SEKOLAH DASAR NEGERI DI KECAMATAN PATAMPANUA KABUPATEN PINRANG
}

\author{
Nurhaedar $^{(1)}$, Rahmi $^{(2)}$
}

\begin{abstract}
Abstrak : Tujuan penelitian yaitu mengembangkan SDM para guru honorer untukmewujudkan kompotensi pedagogic melalui impelementasi pelatihan pengembangan kompetensi pedagogic (guru honorer sekolah dasar) melalaui penelitian tindakan kelas Metode penelitian yang digunakan adalah pengembangan (reseach action and Development) dengan model tindakan implementasi Pelatihan penyusunan dan teknik penulisan laporan analisis tindakan kelas (ATK) Hasil dari penelitian ini yaitu para Guru honorer mampu : (1) mengevaluasi diri dan melakukan pengembangan kinerja (2) Mengelola Program Belajar-Mengajar, mampu Merumuskan tujuan instruksional/pembelajaran, mengenal dan dapat menggunakan proses instruksional yang tepat dengan model aneka sumber melaksanakan program belajar-mengajar mengenal kemampuan anak didik merencanakan dan melaksanakan program remedi. (3) Menganalisa situasi pembelajaran dan menyusun laporan analisis tindakan kelas (ATK), serta melakukan pengembangan pengetahuan, keterampilan dan prilaku dalam sistem pembelajaran untuk meningkatkan mutu pembelajaran.
\end{abstract}

Keyword : Evaluasi kinerja, Kompetensi pedagogik, Peningkatan mutu pembelajaran siswa

\section{PENDAHULUAN}

Secara global salah kreteria yang dijadikan sebagai tolok ukur kemajuan suatu Negara merupakan eksistensi Sumber Daya Manusia karena jika Sumber Daya manusia di Negara tersebut bisa diandalkan maka segala potensi bisa digali dan dimanfaatkan secara efektif, karena Sumber Daya Manusia yang handal merupakan Sumber Daya Manusia selalu berkarya untuk bangsa dan Negara juga dapat mengubah potensi di sektor bisnis (swasta), sebagaimana kita ketahui bahwa di era globalisasi salah objek transaksi bisnis adalah karya intelektual selalu disertai dengan tenaga ahli yang sudah terlatih dalam bidangnya.

Oleh karena itu setiap Negara di berbagai belahan bumi ini baik di Negara Eropa maupun Asia berusaha keras untuk memacu Sumber Daya Manusianya, disertai adanya pertanyaan apa rahasia sukses suatu Negara dalam pembangunan Sumber C 2020 STIE TDN. All rights reserved 
Daya Manusiap Tampaknya kata kunci merupakan pendidikan, oleh karena itu tidak mengherankan bila di perhatikan dari segi anggaran pendidikan yang disediakan oleh Negara-Negara yang terus mengembankan otoritas keilmuannya sehingga sehingga karyakarya para pendidik inipun kerap kali menjadi acuan bagi Negara-negara lain.

Sejalan dengan Penelitian Carnegie Corporation of New York pada tahun 1996 memperlihatkan fakta bahwa peserta didik yang memasuki kelas satu sekolah dasar berada dalam periode transisi dari pertumbuhan pesat masa anak-anak ke fase perkembangan yang lebih bertahap (Slavin, 2008:28). Perubahan dalam perkembangan mental maupun sosial menjadi ciri khas masa-masa sekolah awal. Beberapa tahun kemudian, ketika anak-anak mencapai kelas sekolah dasar yang lebih tinggi, mereka mendekati akhir masa anak-anak dan memasuki masa pra remaja. Keberhasilan anak-anak di sekolah khususnya berperan penting selama masa-masa sekolah awal, karena pada saat sekolah dasarlah mereka mendefinisikan diri sebagai peserta didik (Slavin, 2008:28).

Mencermati kondisi terlebih lagi di era pasar bebas yang syarat dengan profesionalitas merupakan tantangan yang besar bagi setiap sekolah pada umumnya sekolah dasar tersebar disetiap provensi yang terdiri 34 Provensi yang sudah mutlak mencetak bergitu banyak generasi mudah sebagai penerus kemajuan Negara yang di harapkan memiliki pondasi kecerdasan intelek karena tamatan sekolah dasar murupakan wadah pembentukan pondasi dasar pengentahuan,keterampilan, dan prilaku siswa

Oleh karena itu upaya peningkatan kompetensi pedagogik tenaga pengajar sekolah dasar harus sesuai dengan bidang ilmunya utamanya tenaga honorer yang menjadi pokok perhatian Kementrian Pendidikan Indonesia Hal ini didasarkan pada konsepsi bahwa para guru merupakan salah satu komponen yang sangat berperan dalam proses belajar, dan secara langsung mempengaruhi peningkatan kualitas belajar siswa dan kualitas lulusan untuk bekal sekolah lanjutan agar dapat lebih mudah meningkatkan pengetahuan dasar yang dimiliki setiap siswa, maka dengan itu hendaknya tenaga pendidik baik guru pegawai Negeri Sipil maupun guru honorer harus memiliki tiga kompetensi pedagogis, yaitu penguasaan bidang ilmu, keterampilan kurikulum dan sikap (pembelajaran dan pengembangan dan cara mensikapi pemahaman materi) demi peningkatan relevansi dan mutu peranan guru sekolahdasar sehari-hari dalam mencapai kualitas tinggi

Sehubungan dengan Program ilmu yang berkualitas secara berkelanjutan yang merupakan tujuan yang ingin dicapai karena banyak pihak yang memiliki kepentingan meliputi (kepala sekolah,para guru ,siswa, orang tua, serta pemerintah, atas hasil kinerja pencapaian kualitas lulusan bersumber dari kualitas proses belajar yang tidak terlepas dari pencapaian kinerja guru baik sipil maupun honorer. yang harus memiliki kinerja yang maksimal (minimal baik) karena dengan pencapaian kinerja yang sangat baik tentunya akan menghasilkan sumber daya manusia yang berkualitas sesuasi dengan visi 
misi dan tujuan pendidikan Nasional Indonesia.yaitu terwujudnya peserta didik yang beriman,cerdas,terampil, beriman dan berwawasan global

Misi. Menanamkan Keimanan dan ketakwaan melalui pengamalan ajaran agama, Mengoptimalkan proses pembelajaran dan bimbingan., Mengembangkan bidang Ilmu Pengetahuan dan Teknologi berdasarkan minat, bakat, dan potensi peserta didik.,Membina kemandirian peserta didik melalui kegiatan pembiasaan, kewirausahaan, dan pengembangan diri yang terencana dan berkesinambungan.

Menjalin kerjasama yang harmonis antar warga sekolah, dan lembaga lain yang terkait. serta tujuan umum pendidikan dasar, tujuan Mengembangkan budaya sekolah yang religius melalui kegiatan keagamaan, Semua kelas melaksanakan pendekatan pembelajaran aktif pada semua mata pelajaran, Mengembangkan berbagai kegiatan dalam proses belajar di kelas berbasis pendidikan karakter bangsa, Menyelenggarakan berbagai kegiatan sosial yang menjadi bagian dari pendidikan karakter bangsa, Menjalin kerja sama dengan lembaga lain dalam merealisasikan program sekolah. Memanfaatkan dan memelihara fasilitas mendukung proses pembelajaran berbasis TIK.untuk mencapai tersebut maka tenaga pengajar harus kapabilitas dari penerapan kompetensi yang dimiliki demi mewujudkan pencapaian kinerja yang optimal.

\section{Identifikasi Masalah}

Identifikasi masalah dalam penelitian ini antara lain:

1. Ketidak sesuaian bidang ilmu yang dimiliki dengan tugas dan fungsinya kinerja guru honorer masih kurang maksimal karena ini dibuktikan dengan hasil survey tentang alumni sebanyak 600 orang hanya sekitar 27 orang dari 33 Sekolah dasar dikecamatan patampanua yang diterima disekolah menengah pertama yang status sekolah unggulan,dan hasil wawancara beberapa orang tua Murid tentang kondisi pengetahuan dan pemahaman anaknya agak kurang, kondisi tersebut disebabkan kinerja guru horoner kurang optimal karena seperti kita ketehui sekarang ini yang berperan aktif dalam proses pembelajaran siswa disekolah dasar adalah guru honorer.

Fenomena tersebut sudah tentunya ada hal yang mempengaruhi hasil kinerja guruutamanya guru honorer secara internal yaitu ketidaksesuaian bidang ilmu yang dimiliki dengan tugas dan fungsinya sebagai guru sekolah dasar,yang mana pada umumnya guru honorer hanya bermodalkan ijazah sarjana tanpa bekal keterampilan mengajar sehingga kurang mampu mengelola program pembelajaran, penggunaan metode belajar kurang tepat sehingga capaian setiap mata pelajaran kurang tercapai dan secaraeksternal kurangnya honor yang diterima sehingga mempengaruhi motivasi mengajar para guru honorer.

Berdasarkan masalah tersebut maka perlu dilakukan penelitian dengan judul: "Evaluasi Kinerja Dalam Mewujudkan Kompetensi Pedagogik Guru Honorer untuk peningkatan mutu pembelajaran siswa Sekolah Dasar Di Kecamatan Patampanua Kabupaten Pinrang"

sebagai guru sekolah dasar,yang mana pada umumnya guru honorer hanya bermodalkan ijazah sarjana tanpa bekal keterampilan mengajar

C 2020 STIE TDN. All rights reserved

Corresponding Author: 
sehingga kurang mampu mengelola program pemmbelajaran,

2. Penggunaan metode belajar kurang tepat sehingga capaian setiap mata pelajaran kurang tercapai.

3. Kurangnya honor yang diterima sehingga mempengaruhi motivasi mengajar para guru honorer.

\section{Rumusan Masalah}

Setelah mengidentifikasi masalah maka dapat memberikan hasil sebagai rumusan masalah yaitu:

1. Dengan evaluasi kinerja sistempembelajaran guru honorer dapat mengukur sejauh mana kemampuan yang dimiliki dan meningkatkan kompetensi pedagogic guru honorer sekolah dasar

2. Dengan implementasi pelatihan Penelitian tindakan kelas maka guru honorer mampu dalam penguasaan bidang ilmu, keterampilan kurikulum dan sikap (pembelajaran dan pengembangan dan cara mensikapi pemahaman materi dan penggunaan media dan metode yang tepat demi peningkatan relevansi dan mutu peranan guru sekolah dasar sehari-hari.

3. Dengan pelatihan Analisis Tindakan Kelas guru honorerdapat meningkatkan pengetahuan dan keterampilan menyusun dan menulis laporan analisis tindakan kelas

\section{Ruang Lingkup Masalah}

Untuk memperjelas pembahasan pada penelitian ini maka ditentukan ruang lingkup permasalahan pada penelitian ini sebagai berikut:

1. Evaluasi kinerja sistem pembelajaran guru honorer sekolah dasar dikecamatan patampanua kabupaten pinrang
2. Pelatihan penyusunan dan teknik penulisan laporan analisis tindakan kelas.

\section{Tujuan Penelitian}

Berdasarkan permasalahan dan ruang lingkup permasalahan di atas penulis memiliki maksud dan tujuan yang, yaitu untuk Meningkatkan pengetahuan dan keterampilan Para guru honorer sebagai berikut :

1. Mengevaluasi kinerjanya dan dapat mengukur sejauh mana kemampuan yang dimiliki

2. Dalam penguasaan bidang ilmu, keterampilan kurikulum dan sikap (pembelajaran dan pengembangan dan cara menyikapi pemahaman materi dan penggunaan media dan metode yang tepat) demi peningkatan relevansi dan mutu peranan guru sekolah dasar seharihari

3. Penyusunan dan teknik penulisan laporan analisis tindakan kelas.

\section{Manfaat Penelitian}

Dengan menentukan tujuan dari proses penelitian, maka perlu diketahui lebih lanjut manfaat apa saja yang akan diperoleh dalam penelitian ini paraGuru honorer dapat:

1. Mengevaluasi diri dan melakukan pengembangan kinerja

2. Mengelola Program BelajarMengajar, mampu merumuskan tujuan instruksional/pembelajaran, mengenal dan dapat menggunakan proses instruksional yang tepat, melaksanakan program belajarmengajar, mengenal kemampuan anak didik merencanakan dan melaksanakan program remedi.

3. Melakukan pengembangan pengetahuan, keterampilan dan perilaku dalam sistem pembelajaran 
untuk meningkatkan mutu pembelajaran

\section{TELAAH LITERATUR DAN PENGEMBANGAN HIPOTESIS}

\section{Kinerja GuruSekolah dasar}

Kementerian Pendidikan dan Kebudayaan (Kemdikbud) sebagai instansi pembina jabatan fungsional guru merancang Penilaian Kinerja Guru (PKG) dengan mengacu pada empat kompetensi guru. Salah satu fungsi PKG yaitu memonitor kinerja guru. Instrumen PKG dirancang dengan mengkristalisasi dan menemukan gejala-gejala utama yang nampak dalam perilaku guru. Instrumen dirancang agar dapat memotret secara objektif kinerja guru.

Martinis Yamin dan Maisah (2010:87) mengatakan bahwa "Kinerja seorang guru dikatakan baik jika guru telah melakukan seluruh aktivitas yang ditunjukkan dalam tanggung jawabnya untuk mendidik, mengajar, membimbing, mengarahkan, dan memandu peserta didik dalam rangka menggiring perkembangan peserta didik ke arah kedewasaan mentalspiritual maupun fisik-biologis". Aktivitas guru merupakan bentuk implementasi kompetensinya. Rekomendasi dari hasil penelitian Triyono (2014) yaitu bahwa guru harus terus meningkatkan kinerjanya dalam beberapa aspek kompetensi, terutama kompetensi pedagogiknya. Cara meningkatkan kompetensi guru salah satunya dibuktikan dari hasil penelitian Shohibut Tauhid dan Bambang Ferianto T. K. (2014) yang menunjukkan bahwa hasil penilaian kinerja harus ditindaklanjuti dengan supervisi lebih.

Guru sebagai aparatur $(\mathrm{ASN}=$ Aparatur Sipil Negara, maupun aparatur pendidikan) dan sebagai tenaga profesional memiliki kewajiban profesional untuk dinilai kinerjanya. Peraturan Menteri Pendidikan Nasional Nomor 35 Tahun 2010 tentang Petunjuk Teknis Pelaksanaan Jabatan Fungsional Guru dan Angka Kreditnya menjadi acuan dalam melaksanakan PKG. Sistem PKG dirancang dengan memenuhi syarat valid, reliabel, dan praktis (Kemdiknas, 2010). Pengertian valid, reliabel, dan praktis menurut Kemdinas (2010) sebagai berikut: Valid berarti aspek PKG benar-benar mengukur komponen-komponen tugas guru utama dan kompetensi guru. Reliabel berarti instrumen PKG pada waktu digunakan untuk menilai guru mempunyai tingkat kepercayaan dan hasil yang tinggi pada saat digunakan untuk menilai guru oleh siapapun penilainya. Praktis berarti instrumen PKG mudah digunakan dan dalam tingkat validitas dan reliabilitas relatif sama dalam semua kondisi tanpa memerlukan prasyarat

Perbaikan pembelajaran melalui PTK. Untuk mendapatkan hasil belajar yang maksimal, maka guru harus mempersiapkan proses pembelajaran dengan matang dengan memperhatikan hal-hal sebagai berikut : (1) Merumuskan tujuan pembelajaran yang bersifat spesifik dan operasional sehingga dapat diukur untuk membangkitkan motivasi belajar siswa dan siswa bisa mengetahui tentang apa yang dikehendaki guru. Mengembangkan bahan pembelajaran yang sesuai dengan karakteristik dan lingkungan tempat tinggal siswa. Guru akan bisa mengembangkan materi pelajaran apabila guru menguasai pelajaran, dan penguasan materi pelajaran bagi guru merpakan tuntutan profesionalisme bila guru tersebut (C) 2020 STIE TDN. All rights reserved 
ingin mendapatkan hail belajar yang baik, (3) Merumuskan kegiatan pembelajaran dengan memperhatikan langkah-langkah pembelajaran, alat dan sumber bahan serta model pembelajaran yang akan digunakan, disamping itu guru juga wajib memahami prinsip-prinsip mengajar dari yang mudah ke yang sulit, dan konkret ke abstraks. (4) Mengukur keberhasilan siswa guru perlu mengadakan evaluasi mengetahui mengetahui sejauh mana materipelajaran dapat diserap siswa dengan mengetahui hasi belajar yang dicapai siswamaka guru bisa menetukan tindak lanjut.Berdasarkan paparan di atas, maka PTK yang akan dilaksanakan bertujuan untuk meningkatkan hasil belajar siswa kelas $\mathrm{V}$ dengan menggunakan model pembelajaran peer tutoring,

\section{Pengetahuan Pedagogis}

Adalah pengetahuan mengenai ruang kelas, pengaturan ruang kelas dan bagaimana ruang kelas dapat mendorong pembelajaran. Beberapa contoh konsep yang terkait dengan bidang pengetahuan pedagogis ini meliputi hal-hal seperti level-level pembelajaran dalam ranah kognitif, tujuan dan sasaran pengajaran, rencana pelajaran, waktu menunggu, penelitian, aturan dan prosedur serta ujian berdasarkan kriteria. Pengetahuan ketiga yang harus dimiliki guru adalah keterampilan mengajar atau kemampuan untuk menggunakan pengetahuan terkait dengan cara-cara strategis dalam memberdayakan dan melaksanakan pembelajaran peserta didik berdasarkan tiga tugas yang saling berkaitan yakni perencanaan, penerapan dan penilaian. Untuk itu guru harus mampu mengetahui mana strategi pembelajaran yang dirasakan efektif dalam pembelajaran di Sekolah Dasar.

Implikasi perubahan ini adalah semakin tinggi kualitas kompetensi hasil belajar Menurut Munthe (2009:65): Mengajar adalah membuat hasil belajar dapat tercapai (teaching as making learning possible) atau secara kontekstual bahwa mengajar adalah usaha yang memanfaatkan berbagai strategi, metode dan teknik guna memungkinkan tercapainya kompetensi/ hasil belajar tertentu dalam artian, terjadinya perubahan dari tidak bisa menjadi bisa dan tidak mampu menjadi yang diperoleh peserta didik semakin tinggi pula tingkat kualitas kompetisi yang kelak diperankan dalam kenyataan Pembelajaran ruang kelas yang efektif membutuhkan komitmen profesional. Meskipun hal-hal yang terjadi secara tak terduga dan spontan merupakan pengecualian, bukan sesuatu yang biasa terjadi. Jika guru berkeinginan memelihara lingkungan yang berorientasi pada kesuksesan (successoriented environment) dengan cara mengembangkan pembelajaran peserta didik selama satu tahun ajaran, mereka harus terus menerus membidik dan memerhatikan aksi pengajaran yang di dalamnya terdiri dari tahap perencanaan (planning) dan penerapan (implementing) aktivitas-aktivitas pengajaran serta penilaian (assessing) performa peserta didik. Menurut (Jacobsen, David A.;Eggen, Paul; Kauchak, Donald (2009:34). Belajar untuk mengajar (learning to teach) mempunyai kompleksitas dan bervariasi dalam arti bahwa tindakan ini mengharuskan adanya beragam jenis pengetahuan yang berbeda-beda. Beberapa pengetahuan itu antara lain: (1) pengetahuan konten/isi (content (C) 2020 STIE TDN. All rights reserved 
knowledge) yang bisa dilihat dalam Permendiknas No. 22 tahun 2006 tentang standar isi; (2) Pengetahuan pedagogik (pedagogical knowledege) yang dapat dilihat dalam Permendiknas Nomor 16 Tahun 2007 tentang Standar Kualifikasi Akademik dan Kompetensi Guru, dan (3) Keterampilan mengajar (teaching skills) Pengetahuan konten guru didasarkan pada seberapa banyak waktu yang di habiskan guru dalam berbagai pelatihan dan bacaan yang menunjang kepada peningkatan profesional karena guru tidak bisa mengajarkan apa yang tidak diketahui.

\section{Metode Pembelajaran berbasis aneka sumber}

Metode Pembelajaran berbasis aneka sumberBintang Petrus Sitepu (2014:33-36) menyatakan bahwa belajar dan membelajarankanberbasis aneka sumber pada hakekatnya merupakan proses belajarmembelajarankan menggunakan berbagai sumber sehingga memungkinkan setiap pemelajar memperoleh kesempatan belajar sesuai dengan gaya dan kecepatan belajarnya sendiri,selain itubelajar berbasis aneka sumber bertujuan melatih pemelajar belajar secara mandiri mengetahui apa yang apa yan harus dipelajari,bagamana cara mempelajarinya,serta memilih dan menentukan sumber belajar yang sesuai.

Teori Reigeluth dan Belt (1994\&1997) dalam Bintang Petrus Sitepu bahwa pendekatan yang semula kepada guru (teacher oriented approach) bergeser kesiswa (student oriented approach) dari anggapan ruang belajar dibatasi dinding,lantai dan langit-langit, meluas menjadi dunia tanpa batas, dari tempat dan waktu belajar secara leluasa,sistem evaluasi yang semula berpatokan pada penguasaan bahan pelajaran,beruba menjadi berpatokan penguasaan kemampuan,sumber belajar sebelumnya mengacu pada teknologi informasi dan komunikasi.

\section{Desain Dan Implementasi Pelatihan}

Desain pelatihan atau rancangan pelatihan menurut Prasetyo (2017:92) bahwa rencana bangunan pelatihan yang terdiri dari beberapa komponenyang saling berkaitan satu sama lain, komponen tersebut adalah tujuan intruksional, strategi intruksional, bahan ajar, dan secara teknis, komponen lainnya adalah: GBPP,SAP.

Lebih Lanjut Prasetyo (2017:107) menjelaskan bahwa kulitas pelatihan pada saat di implementasikan dilapangan sangat di pengaruhui oleh beberapa hal termasuk fasilitas kelas, kretifitas instruktur, agar implemetasi pelatihan lancer ada baiknya kita memperhatikan saran diberikan oleh Keller di sebut sebagai teori ARCS (Attiention (perhatian peserta), Relevansi (Relevasi) dengan tufoksi guru kelas sekolah dasar,Confidence (kepercayaan diri para guru honorer untuk menguasai meteri pelatihan dan memperaktekkan, Satisfaction (kepuasan peserta) tentang meteri yang diterima mampu memenuhi kebutihan untuk meningkatkan kualitas diri.

\section{Kerangka Dan Konsep Penelitian}

Untuk lebih memperjelas arah penelitian maka penulis membuat kerangka pemikiran dengan berbasis rumusan masalah, yang telah ditentukan dengan pendekatan 
Evaluasi kinerja sistem pembelajaran

Pinrang dengan pengukuran dalam mewujudkan kompetensi peningkatan pengetahuan, pedagogis guru honorer sekolah dasar keterampilan dan prilaku guru honorer di Kecamatan Panua Kabupaten dalam sistem pembelajaran

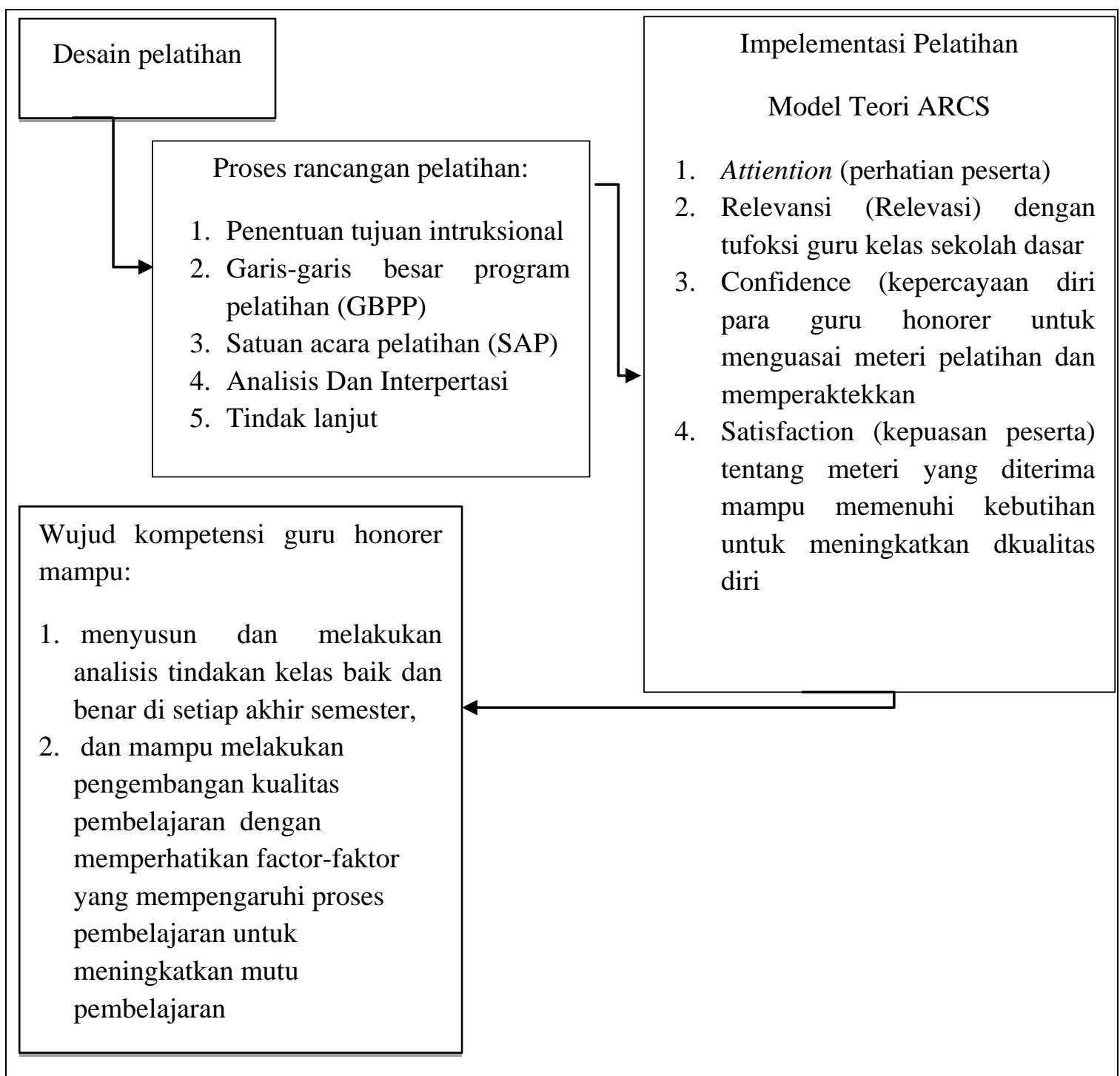

Gambar 1.2 Kerangka Konseptual

\section{Hipotesis}

Berdasarkan kerangka konsep yang telah diuraikan diatas, maka hipotesis dari penelitian ini yaitu sebagai berikut:

1. Diduga dengan evaluasi kinerja sistem pembelajaran guru honorer dapat mengukur sejauh mana kemampuan yang dimiliki
2. Diduga dengan pelatihan Kelompok kerja guru (KKG) model aneka sumber.guru honorer mampu dalam penguasaan bidang ilmu, keterampilan kurikulum dan sikap (pembelajaran dan pengembangan dan cara mensikapi pemahaman materi) demi peningkatan relevansi dan mutu C 2020 STIE TDN. All rights reserved

Corresponding Author: 
peranan guru sekolah dasar seharihari.

3. Diduga dengan pelatihan Analisis Tindakan Kelas guru honorer memiliki pengetahuan dan keterampilan menyusun dan menulis Analisis tindakan kelas

\section{METODE PENELITIAN}

Untuk mencapai tujuan yang diinginkan, penelitian ini dilakukan sesuai dengan tahapan penelitian

\section{Tahapan Penelitian}

Penelitian ini akan dilakukan dengan tahapan sebagai berikut

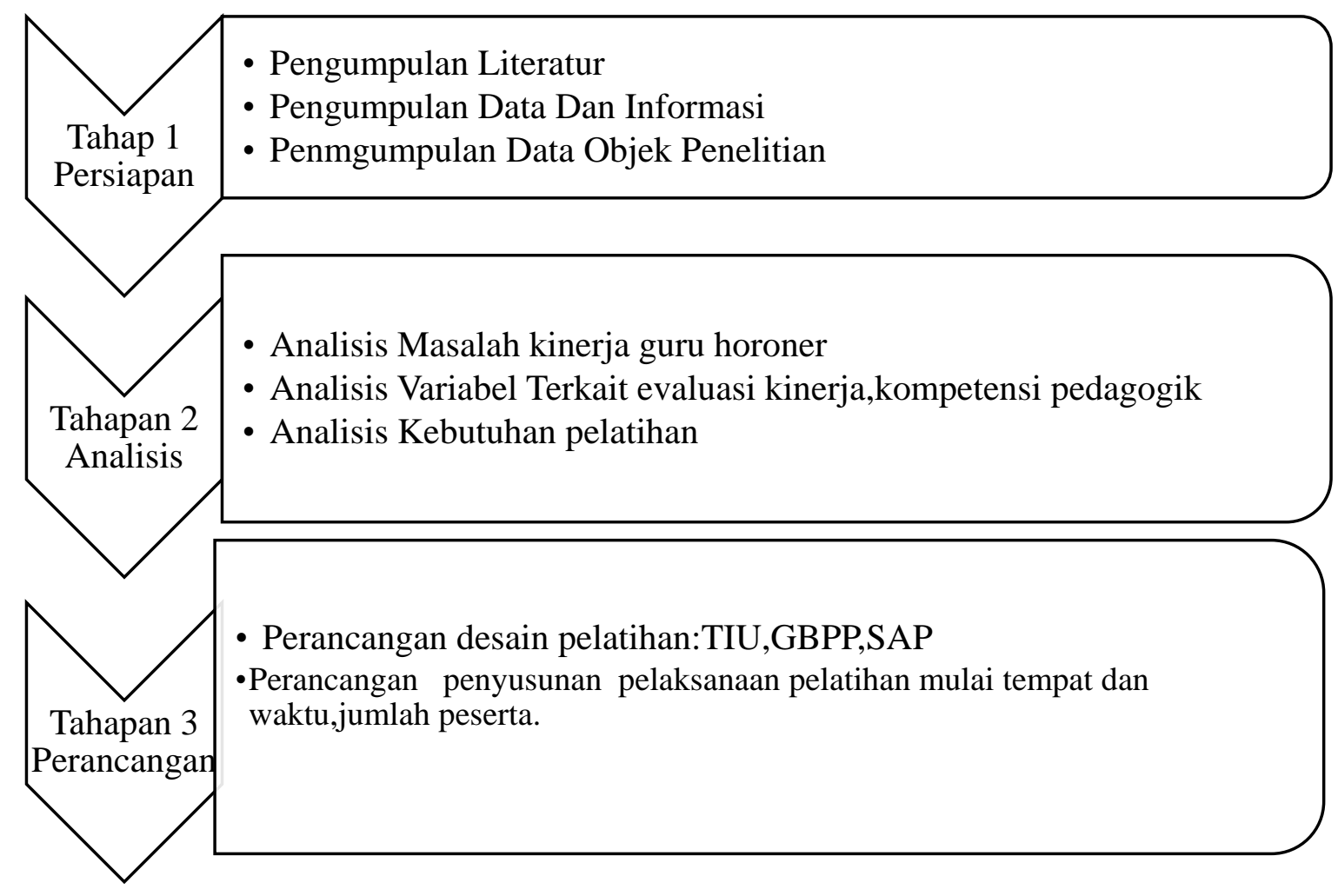




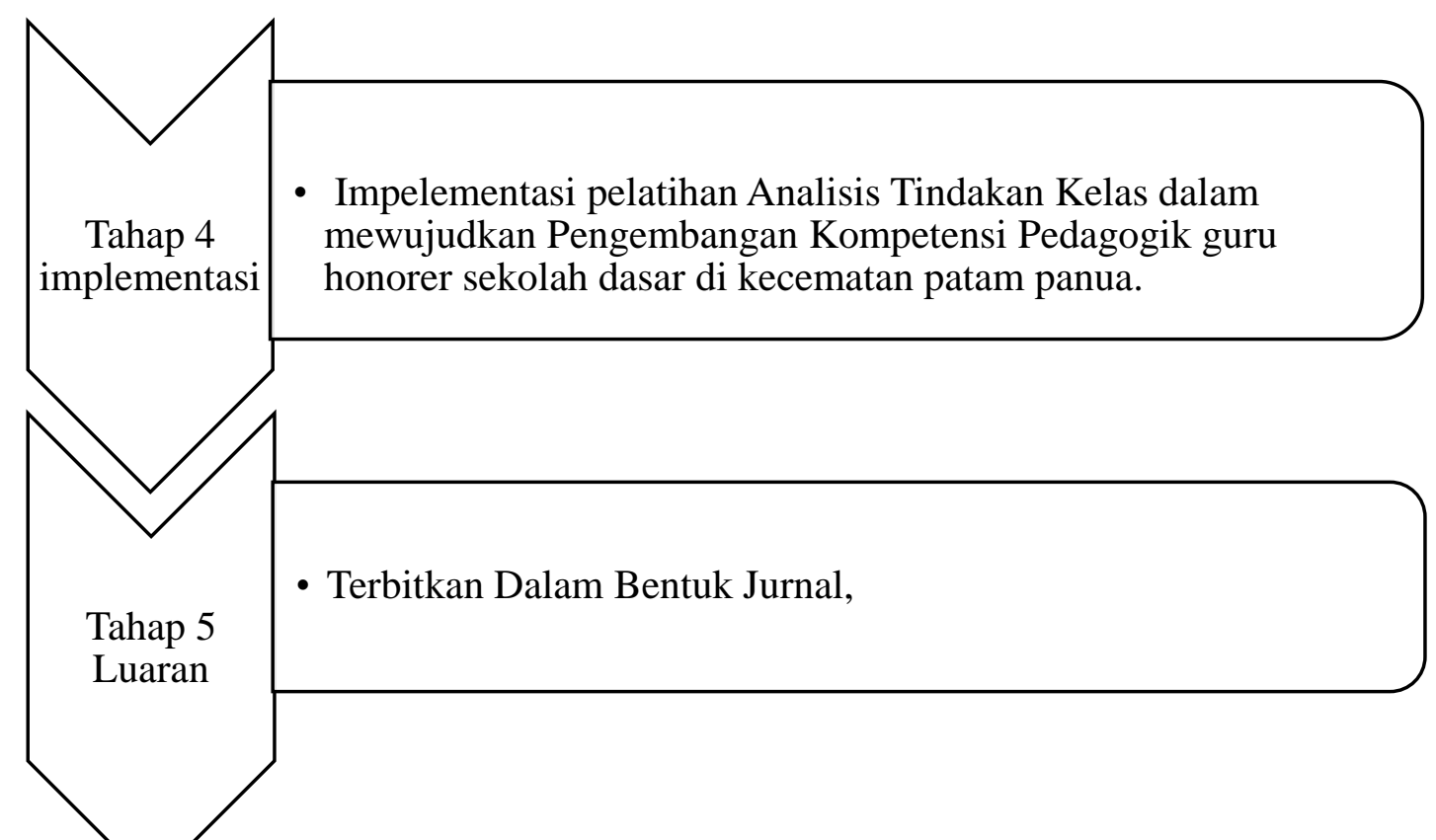

\section{Lokasi Penelitian}

Penelitian ini dilakukan sekolah dasar di Kecamatan Patampanua Kabupaten Pinrang yaitu terdiri 7 desa dan 4 kelurahan sebanyak 32 sekolah dasar Negeri No112, 126, 115, 217 di desa Mattiro Ade, sekolah dasar Negeri No114, 194, di desa Leppangan, sekolah dasar Negeri No113, Sali-Sali di desa Pincara, sekolah dasar Negeri No127 di desa Masolo, sekolah dasar Negeri No122, 117, 293, 259 di desa Sipatuo, sekolah dasar Negeri No195, 121, 195, 123 di desa Malimpung, sekolah dasar Negeri No 260, Pelita, Padang Loang di desa Padang Loang, sekolah dasar Negeri No 128, 183, 257 di Kelurahan Teppo, sekolah dasar Negeri No 292, 119, 129, 167 di Kelurahan Tonyamang, sekolah dasar Negeri No 116, 118, 130, 218 di Kelurahan Benteng, sekolah dasar Negeri No 258 di Kelurahan Maccarinna

\section{Teknik Pengumpulan Data}

Adapun teknik pengumpulan data dalam penelitian ini sebagai berikut:
1. Studi Litaratur dengan cara mengambil data refrensi yang berbeda-beda sumber dari jurnal penelitian dosen pemula, jurnal yang berkaitan dengan desa, buku dan majalah.

2. Observasi melakukan pengamatan langsung proses pembelajaran, fasilitas dan ruang kelas

3. Metode quesioner dengan mengajukan pertanyaan tersetruktur mengenai tanggapan siswa dan rekan guru lainnya tentang proses pembelajaran fasilitas dan ruang kelas

4. Wawancara dengan mengajukan pertanyaan yang sama oleh beberapa siswa, rekan guru tentang proses pembelajaran fasilitas dan ruang kelas.

\section{Jenis Penelitian}

Metode yang digunakan adalah penelitian pengembangan (reseach and Development) dengan model tindakan impelementasi pelatihan ATK dengan Mewujudkan Kompetensi PedagogikGuru Honorer untuk C 2020 STIE TDN. All rights reserved 
peningkatan mutu pembelajaran siswa Sekolah Dasar DiKecamatan Patampanua Kabupaten Pinrang" adapun tujuan akhir penelitian ini mewujudkan kompetensi pedagogik guru honorer untuk peningkatan mutu pembelajaran siswa Sekolah Dasar Di Kecamatan Patampanua Kabupaten Pinrang"

\section{Variabel perubah Yang Diukur}

Evaluasi kinerja guru honorer, kompetensi pedagogik, dan peningkatan mutu pembelajaran.

\section{HASIL DAN PEMBAHASAN}

\section{Impelementasi Pelatihan}

Penelitian ini

mengimplementasikan sumber daya manusia (kompetensi pedagogik guru honorer) melalui Penelitian tindakan kelas, dengan rancangan desain penelitian terdiri dari beberapa komponen yaitu:

1. Tujuan intruksional Umum: Setelah mengikuti pelatihan ini para guru honorer mampu meningkatkan kompetensi pedagogic dengan cara melakukan Analisis tindakan kelas untuk mengevaluasi diri (kinerja).

2. Tujuan intruksional khusus: Diharapakan Para guru honorer mampu menyusun dan melakukan analisis tindakan kelas baik dan benar di setiap akhir semester, dan mampu melakukan pengembangan kualitas pembelajaran dengan memperhatikan faktor-faktor yang mempengaruhi proses pembelajaran.

3. Garis-garis program pelatihan (GGPP): dengan pokok bahasan pengertian kinerja guru, analisis kinerja guru kelas SD, Teknik Penyusunan analisis tindakan tindakan kelas, Komponen-komponen yang diukur(dinilai) dalam proses pembelajaran, perumusan solusi permasalahan factor-faktor yang mempengaruhi proses pembelajaran.

4. Satuan Acara Pelatihan (SAP): Pengembangan Sumber daya Manusia (kompetensi pedagogic guru honorer) melalui Penelitian tindakan kelas.
a. Tujuan Intruksional Umum: Setelah mengikuti pelatihan ini para guru honorer mampu menginkatkan kompetensi pedagogic dengan melakukan penelitian tindakan kelas.
b. Pokok bahasan : Analisis kinerja dengan melakukan penelitian tindakan kelas untuk meningkatkan kompetensi pedagogic guru kelas honorer sekolah dasar di kecamatan Patampanua Kabupaten Pinrang
c. Durasi Pelatihan : Pukul (08.00 - 17.00) Waktu Indonesia Timur
d. Kegiatan Intruksional:

\begin{tabular}{|l|l|l|l|l|l|}
\hline No & Kegiatan Pokok & Waktu & \multicolumn{2}{|c|}{ Kegiatan } & $\begin{array}{l}\text { Bahan Ajar dan } \\
\text { media Intruksional }\end{array}$ \\
\cline { 4 - 5 } & & & Pemateri & Peserta & \\
\hline I & PENDAHULUAN & $08-08.10$ & $\begin{array}{l}- \text { Menjelaskan: } \\
- \text { TIK } \\
- \text { Deskripsi Singkat }\end{array}$ & Menyimak & $\begin{array}{l}\text { Power } \\
\text { Point/LCD/Laptop }\end{array}$ \\
\hline II & PENYAJIAN & $08.10-10.00$ & $\begin{array}{l}\text {-Menjelaskan } \\
\text { pengertian } \\
\text { kinerja(analisis }\end{array}$ & & \\
Point.
\end{tabular}

(C) 2020 STIE TDN. All rights reserved

Corresponding Author: 


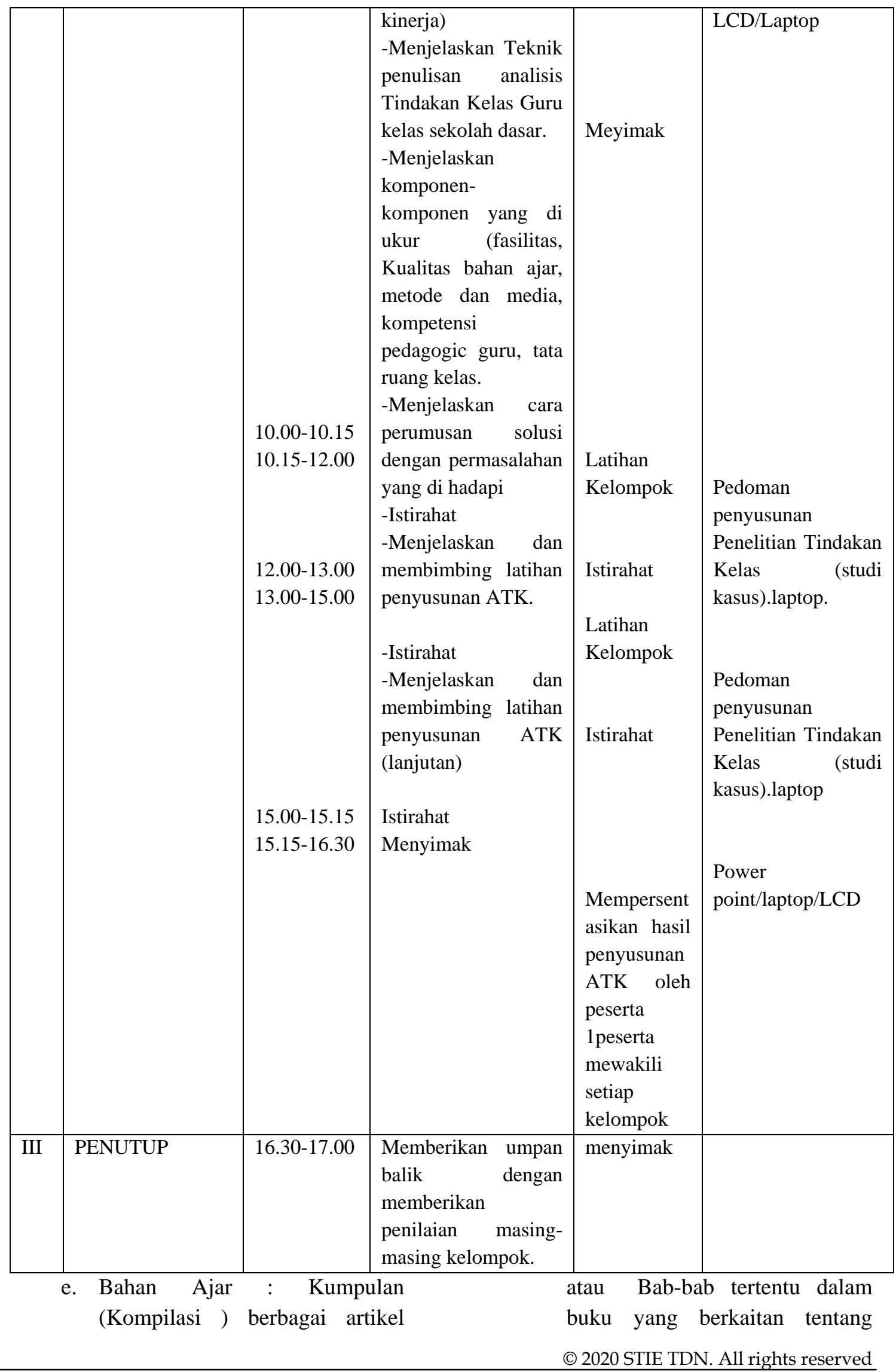

Corresponding Author: 
implemetasi pelatihan ,analisis kinerja guru kelas sekolah dasar dan teknik penelitian tindakan kelas.

f. Media Intruksional: OHP, Panduan Teknik Penulisan

\begin{tabular}{|l|l|l|}
\hline No. & Hambatan & Penanganan \\
\hline 1. & $\begin{array}{l}\text { Jarak tempuh sebagian sekolah tidak } \\
\text { dijangkau kendaraan umum, }\end{array}$ & $\begin{array}{l}\text { Memberikan pemahaman bahwa proses } \\
\text { penelitian bukan mencari kesalahan } \\
\text { melaingkan mencari kebenaran }\end{array}$ \\
\hline 2. & $\begin{array}{l}\text { Sebagian guru honorer sulit untuk } \\
\text { diajak kerjasama dalam realisasi } \\
\text { penelitian atau ikut berpartisipasi ikut } \\
\text { pelatihan, dengan alasan tidak ada } \\
\text { biaya transportasi }\end{array}$ & $\begin{array}{l}\text { Memberikan pengetian atau penjelasan } \\
\text { tentang proses penelitian yang dilaksanakan }\end{array}$ \\
\hline
\end{tabular}

\section{DAFTAR PUSTAKA}

Anonim,2018 Data guru sekolah dasar Negeri Kecamatan Patampanua Kabupaten Pinrang

2010. Undang-Undang Nomor 23 Tahun 2003 tentang Sistem Pendidikan Nasional. Bandung:

Aji 2012. Kelebihan dan Kekurangan Pembelajaran Group Investigation. Diakses dari: http://discussionlecture.blogspo t.co.id/2012/09/kelebihan-dankekurangan pembelajaran.html . pada tanggal 23 Desember 2016

Basri, Hasan. 2015. Paradigma Baru Sistem Pembelajaran. Bandung: Pustaka Setia.

Depdiknas. 2006. Undang-Undang Nomor 20, Tahun 2003, tentang Sistem Pendidikan Nasional. Bandung: Nuansa Aulia.
Analisis Tindakan Kelas, Studi Kasus ATK.

\section{Hambatan Yang Dihadapi}

Penanganan

B.P Sitepu.2014 Pengembangan Sumber Belajar. Penerbit Rajawali Pres,Jakarta

Hasibuan, 2011 Manajemen Sumber Daya Manusia edisi Revisi Penerbit Bumi Aksara

Huda, Miftakhul. 2015. Model-model Pengajaran dan Pembelajaran. Yogyakarta: PT Pustaka Pelajar.

Irham Fahmi,2014 Manajemen Teori, Kasus, dan solusi Penerbit Alfa Beta Bandung

Rivai vietzhal, 2009, Manajemen Sumber Daya Manusia Untuk Perusahaan, edisi I Rajawali Press Jakarta.

Sardiman

A,M 2014

Intraksi\&Motivasi Belajar Mengajar Penerbit Rajawali Pres,Jakarta

Sugiono,2010 Metode Penelitian kualntitatif Kualitatif Dan $R \& D$ penerbit Alfa Beta Bandung (C) 2020 STIE TDN. All rights reserved 
Sugiono,2014 Metode Penelitian

Bisnis Penerbit Cetakan ke 18

Alfa Beta Bandung.

Usman Husaini,2010 Manajemen

Teori, Pratik Dan Riset

Pendidikan Penerbit Bumi

Aksara Jakarta.

(C) 2020 STIE TDN. All rights reserved

Corresponding Author:

60 